William R. Wiley
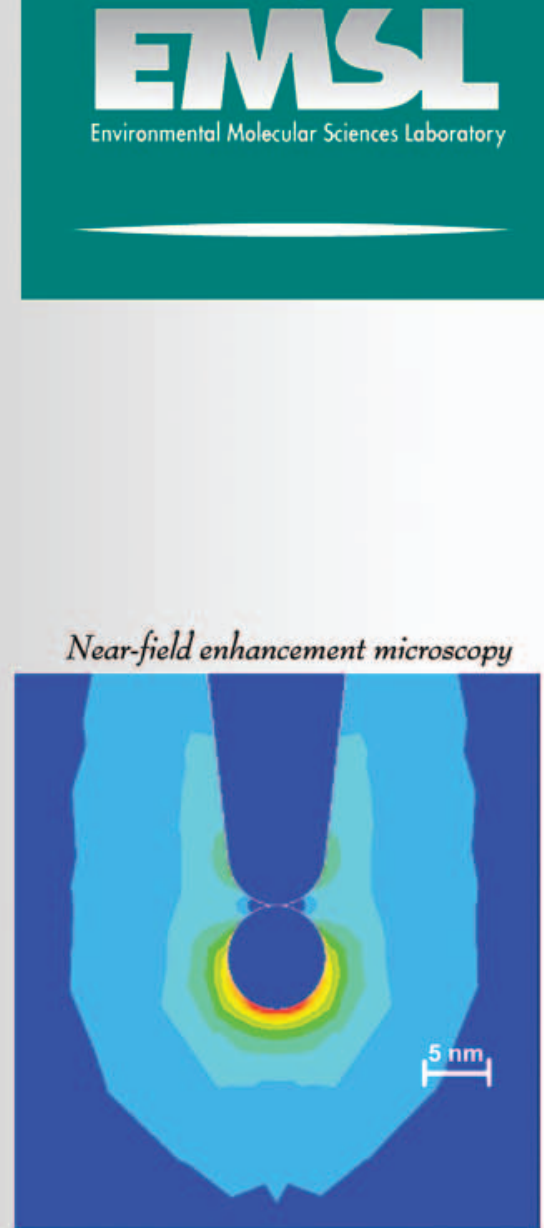

Annual Report

Chemical Structure

and Dynamics

October 2002

Pacific Northwest National Laboratory

Operated by Battelle for the U.S. Department of Energy

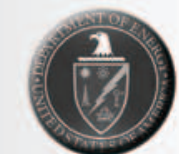


Cover Photo: Finite element method simulation of the atomic force microscopy (AFM)

tip induced optical-field enhancement near a metallic nano-particle, a new approach for AFM-surface enhanced Raman microscopy (AFM-SERS). The illustration shows the distribution of an enhanced electric field in the vicinity of a nano-particle (dia.10nm) when approached from above by a silver AFM and exposed under the laser illumination with vertical polarization. By using a frequency-domain 3D finite element method to solve Maxwell's equations, CS\&D researcher Miodrag Micic, Nicholas Klymyshyn, and H. Peter Lu simulated the electric field enhancement distribution as a function of the geometrical and optical parameters. Ongoing research suggests possible new approaches for enhancing the spatial and compositional resolution of the AMS-SERS imaging and microanalysis of samples on surfaces, as well as for nano-particles embedded under lipid membranes.

\title{
DISCLAIMER
}

This report was prepared as an account of work sponsored by an agency of the United States Government. Neither the United States Government nor any agency thereof, nor Battelle Memorial Institute, nor any of their employees, makes any warranty, express or implied, or assumes any legal liability or responsibility for the accuracy, completeness, or usefulness of any information, apparatus, product, or process disclosed, or represents that its use would not infringe privately owned rights. Reference herein to any specific commercial product, process, or service by trade name, trademark, manufacturer, or otherwise does not necessarily constitute or imply its endorsement, recommendation, or favoring by the United States Government or any agency thereof, or Battelle Memorial Institute. The views and opinions of authors expressed herein do not necessarily state or reflect those of the United States Government or any agency thereof.

\author{
PACIFIC NORTHWEST NATIONAL LABORATORY \\ operated by \\ BATTELLE \\ for the \\ UNITED STATES DEPARTMENT OF ENERGY \\ under Contract DE-ACO6-76RLO183O
}

Printed in the United States of America

Available to DOE and DOE contractors from the

Office of Scientific and Technical Information,

P.O. Box 62, Oak Ridge, TN 37831-0062;

ph: (865) 576-8401

fax: (865) 576-5728

email: reports@adonis.osti.gov

Available to the public from the National Technical Information Service, U.S. Department of Commerce, 5285 Port Royal Rd., Springfield, VA 22161 ph: (800) 553-6847 fax: (703) 605-6900

email: orders@ntis.fedworld.gov

online ordering: http://www.ntis.gov/ordering.htm

This document was printed on recycled paper. 
Annual Report

\section{Chemical Structure and Dynamics}

Steven D. Colson, Associate Director

R. E. Gephart, Program Manager

and the Staff of the Chemical Structure and Dynamics Program

October 2002

Prepared for the U.S. Department of Energy under Contract DE-AC06-76RL01830 


\section{Contents}




\section{Introduction}

Chemical Structure and Dynamics

Program.

$1-1$

\section{Reaction Mechanisms at Solid, Liquid, and Gas Interfaces}

Structure and Reactivity of Ices, Oxides, and Amorphous Materials at Surfaces and Interfaces

J. Daschbach, P. Ayotte, G. Kimmel,

B. Peden, G. Schenter, R. S. Smith, and

B. D. Kay .

Mixing, Transport, and Phase Separation

in Deeply Supercooled, Metastable

Binary Solutions

P. Ayotte, R. S. Smith, G. Teeter,

Z. Dohnálek, G. A. Kimmel, and

B. D. Kay ....

Adsorption Dynamics and Desorption

Kinetics on Oxide Surfaces

Z. Dohnálek, R. S. Smith,

and B. D. Kay

Synthesis and Characterization of

Nanoporous Thin Films Using Molecular

Beam Techniques

Z. Dohnálek, G. A. Kimmel,

D. E. McCready, J. S. Young,

A. Dohnálková, R. S. Smith, and

B. D. Kay

Solvation at the Oil-Water Interface and

Nano-Structured Fluids

J. P. Cowin, M. J. Iedema,R. C. Bell, and $H$. Wang

Nitric Acid-Water Complexes:

Theoretical Calculations and Comparison

to Experiment

P. R. McCurdy, W. P. Hess, and

S. S. Xantheas

\section{High-Energy Processes at Environmental Interfaces}

Control of Laser Desorption Using

Tunable Single Pulses and Pulse Pairs

W. P. Hess, A. G. Joly, D. P. Gerrity,

K. M. Beck, P. V. Sushko, , and

A. L. Shluger

Transient Center Photodecomposition in

Potassium Bromide

K. M. Beck, A. G. Joly, W. P. Hess,

D. P. Gerrity, N. F. Dupuis, P. V. Sushko

and A. L. Shluger. 3-3

Selective Laser Desorption of Ionic

Surfaces: Resonant Surface Excitation of

$\mathrm{KBr}$

W. P. Hess, A. G. Joly, D. P. Gerrity,

K. M. Beck, P. V. Sushko, and

A. L. Shluger. 3-6

Femtosecond Time-Resolved Photo-

Stimulated Desorption of Positive Ions

from Ionic Crystals

A. G. Joly W. P. Hess, K. M. Beck, and

J. T. Dickinson........................................... 3-8

$\mathrm{Up}$-Conversion Luminescence of $\mathrm{Mn}^{2+}$ in ZnS: $\mathrm{Mn}^{2+}$ Nanoparticles

W. Chen, A. G. Joly, and J. Z. Zhan

Vehicle Exhaust Treatment Using

Electrical Discharge Methods

R. G. Tonkyn, S. E. Barlow, A. Ebeling,

C. H. F. Peden

Electron-Stimulated Reactions at Surfaces and Interfaces

G. A. Kimmel and N. G. Petrik

XAFS Study of Rare Earth Element

Coordination in Calcite

E. J. Elzinga, R. J. Reeder, S. H. Withers,

R. E. Peale, R.A. Mason, K. M. Beck,

and W.P. Hess $3-21$ 
Preparation of $\mathrm{Pt} / \mathrm{TiO}_{2}$ Nanocomposite

Thin Films by Pulsed Laser Deposition

and Their Photoelectrochemical

Behaviors

T. Sasaki, N. Koshizaki, J. W. Yoon, and K. M. Beck.

\section{Cluster Models of the} Condensed Phase

Clusters and Multiply Charged Anions:

Model Studies and Solvations

L. S. Wang, X. B. Wang, X. Yang,

J. B. Nicholas, and E. R. Vorpagel

Probing the Electronic Structure of Transition

Metal Clusters and Complexes

L. S. Wang, X. B. Wang, H. J. Zhai

S. Liu, R. Brown, P. Schwerdtfeger,

D. Schroder, H. Schwartz, G. L. Gutsev,

and P. Jena

Investigation of Metal-Carbon

Mixed Clusters and Aluminum Alloy Clusters

L. S. Wang, X. Li, H. F. Zhang,

H. J. Zhai, A. I. Boldyrev, and

J. D. Corbett

High Resolution Infrared Spectroscopy of

Small Molecular Clusters

T. A. Blake, R. L. Sams, S. W. Sharpe,

and S. S. Xantheas

\section{Single-Molecule Spectroscopy and Biological Imaging}

Single-Molecule Nanosecond Anisotropy

Dynamics of Tethered Protein Diffusion

D. Hu and H. P. Lu

Single-Molecule Dynamics of Protein-

DNA Interactions in DNA Damage

Recognition

H. Peter Lu, Lilia M. Iakoucheva, and Eric J. Ackerman
Revealing Function-Regulating

Conformational Dynamics of an Ion

Channel by Simultaneous Single-

Molecule Fluorescence Imaging and

Patch-Clamp Recording

G. Harms, G. Orr, B. Thrall, S. Colson,

M. Montal, and H. P. Lu

Single-Molecule Spectroscopy Studies of

Dynamic Protein-Protein Interactions in

Cellular Signaling

X. Tan, K. Hahn, and H. P. Lu

Surface Enhanced Raman Spectroscopy

of Nanoparticles and Nanostructures:

Towards Vibrational Mode-Specific

Single-Molecule Electron Transfer

Dynamics

L. Zhu, G. Schenter, Y. D. Suh, and

H. P. Lu

Probing Single-Molecule Conformational

Mode-Specific Dynamics under

Enzymatic Reaction Conditions in Real

Time

Y. Chen, D. Hu, E. R. Vorpagel, and

H. P. Lu

Improving Image Quality in CARS

Microscopy Using Spectroscopic Markers

and New Optical Methods

G. R. Holtom, B. D. Thrall,

S. D. Colson, and C. S. Chen

\section{Ultrasensitive and Environmental Analysis}

The PNNL Electron Microbeam

G. Kimmel, M. S. Resat, B. Thrall,

L. Kathman, J. Miller, and D. Strom .......

Chemistry of Atmospheric Aerosols A. Laskin, M. J. Iedema, J. P. Cowin, R. S. Disselkamp, C. M. Berkowitz, and J. S. Young.... 6-6 
Laboratory Measurement of Water

Nucleation Using a Laminar Flow Tube

Reactor

V. B. Mikheev, P. M. Irving,

N. S. Laulainen S. E. Barlow,

and V.V.Pervukhin.

High Resolution Infrared Spectroscopy

Facility

T. A. Blake, R. S. Disselkamp,

T. J. Johnson, J. F. Kelly, R. L Sams, and $S$. W. Sharpe

\section{Appendix}

Chemical Structure and Dynamics Staff....... 7-1

Associate Director, EMSL .......................... 7-1

Program Manager............................................ 7-1

Operations Administrator.............................. 7-1

Office Support........................................... 7-1

Staff ........................................................ 7-1

Research Scientists................................... 7-3
Scientists Emeritus........................................ 7-4

Postdoctoral Fellows...................................... 7-4

Graduate Students ........................................ 7-6

Undergraduate Students............................... 7-6

Publications and Presentations from

October 2000 to December 2001 ............ 7-7

Publications................................................. 7-7

In Press .................................................. 7-11

Presentations ............................................... 7-12

Patents ..................................................... 7-18

Honors and Recognition ............................... 7-18

Collaborations.............................................. 7-19

Publications and Presentations from

January 2002 to September 2002 ........... 7-23

Publications................................................... 7-23

In Press ..................................................... 7-25

Presentations …............................................. 7-25

Acronyms and Abbreviations ........................ 7-29 
